\title{
Analisis Biaya Pengangkutan Sampah Rumah Tangga Eksisting di Kota Cimahi
}

\author{
SITI S. ANGGUNISA HERYENI ${ }^{1}$, YULIANTI PRATAMA ${ }^{1}$, NICO HALOMOAN ${ }^{1}$
}

1. Jurusan Teknik Lingkungan, Fakultas Teknik Sipil dan Perencanaan, ITENAS, Bandung

Email : sitisholehaanggunisa@yahoo.com

\begin{abstract}
ABSTRAK
Biaya rerata pengelolaan sampah di Kota Cimahi (2012-2016) mencapai \pm 13 miliar rupiah dengan penerimaan rerata retribusi sampah hanya \pm 1 miliar rupiah. Biaya pengelolaan sampah kota dipengaruhi oleh timbulan sampah, dimana sebesar 63\% sampah kota berasal dari permukimandengan penerimaan retribusi sampah (permukiman) rerata (2012-2016) hanya \pm 784 juta rupiah. Penelitian ini dilakukan analisis biaya pengangkutan sampah rumah tangga eksisting di Kota Cimahi. Metode analisis data yang digunakan adalah deskriptif-kuantitatif. Analisis biaya pengangkutan dilakukan dengan membandingkan penerimaan retribusi sampah dengan biaya pengangkutan, serta dilakukan perbandingan dengan Kota Yogyakarta. Berdasarkan hasil analisis diperoleh bahwa kontribusi penerimaan retribusi sampah permukiman terhadap biaya pengangkutan hanya $19 \%$, artinya kontribusi penerimaan retribusi sampah relatif kecil dan tidak dapat dijadikan sumber anggaran utama.
\end{abstract}

Kata kunci: Biaya Pengangkutan Sampah, Retribusi Sampah Rumah Tangga, Kota Cimahi

\begin{abstract}
The average cost of solid waste management in Cimahi City (2012-2016) reaches \pm 13 billion rupiah with the average revenue of waste levies is only \pm 1 billion rupiah. The cost of municipal solid waste management is influenced by waste generation, which 63\% of the waste comes from household with average waste collection (household) (2012-2016) is only \pm 784 million rupiah. Data analysis method used is descriptive-quantitative. Transportation cost analysis is done by comparing the acceptance of wastecollection with transportation cost, and comparing with Yogyakarta city. Based on the analysis result, it is found that the contribution of waste collection with transportation cost is only 19\%, that means the contribution of waste retribution acceptance is relatively small and can not be used as the main budget source.
\end{abstract}

Keywords:Cost of Transportating Waste, Domestic Waste Collection, Cimahi City 


\section{PENDAHULUAN}

Jumlah penduduk dan tingkat pendapatan masyarakat dapat mempengaruhi timbulan sampah yang dihasilkan. Peningkatan timbulan sampah sebaiknya disertai dengan sistem pengelolaan sampah yang baik dan benar, agar dapat mewujudkan kota yang bersih dan nyaman bagi masyarakat. Aspek pembiayaan merupakan sumber daya penggerak agar roda sistem pengelolaan persampahan dapat berfungsi dengan baik. Oleh karena itu, pemerintah daerah wajib membiayai penyelenggaraan pengelolaan sampah, dimana pembiayaan bersumber dari Anggaran Pendapatan dan Belanja Daerah (APBD).

Kota Cimahi memiliki luas wilayah sebesar $4.025 \mathrm{Ha}$ dengan jumlah penduduk pada tahun 2016 adalah 594.154 jiwa, dan tingkat pelayanan sampah sebesar 79,5\%, serta tingkat pengangkutan sampah ke Tempat Pembuangan Akhir (TPA) sebesar 73,5\% (Dinas Lingkungan Hidup Kota Cimahi, 2016). Akibat dari keterbatasan lahan yang dimiliki, Kota Cimahi tidak memiliki TPA sendiri, sehingga sampah yang dihasilkan dibuang ke TPA Sarimukti.

Terkait pembiayaan pengelolaan sampah di Kota Cimahi, total biaya rata-rata pengelolaan sampah pada tahun 2012-2016 di Kota Cimahi mencapai \pm 13 miliar rupiah, sedangkan total penerimaan rata-rata retribusi pelayanan persampahan mencapai \pm 1 miliar rupiah atau hanya $\pm 8 \%$ dari biaya pengelolaan sampah Kota Cimahi. Besarnya biaya pengelolaan sampah kota dipengaruhi oleh timbulan sampah wilayah yang terlayani. Sumber sampah yang berkontribusi besar sebagai penghasil sampah di Kota Cimahi sebesar 63\% berasal dari aktivitas permukiman. Masyarakat di Kota Cimahi sebagai penghasil sampah berkontribusi dalam sistem pengelolaan sampah, salah satunya adalah dengan membayar retribusi pelayanan persampahan. Retribusi sampah dipungut untuk membayar jasa pengangkutan sampah dari TPS ke TPA, dimana penerimaan retribusi sampah rerata dari sumber sampah permukiman pada tahun 2012-2016, yaitu hanya \pm 784 juta rupiah (Dinas Lingkungan Hidup Kota Cimahi, 2016).

Selain itu, biaya pengangkutan akan semakin meningkat dikarenakan mulai dari jangka menengah (tahun 2021-2025) hingga jangka panjang (tahun 2026-2037) pada Rencana Induk Persampahan Kota Cimahi, tempat pemrosesan akhir sampah akan dialihkan dari TPA Sarimukti ke TPA Legok Nangka. Jarak pengangkutan sampah dari Kota Cimahi ke TPA Sarimukti mencapai $\pm 31 \mathrm{~km}$, sedangkan jarak pengangkutan sampah dari Kota Cimahi ke TPA Legok Nangka mencapai $\pm 58 \mathrm{~km}$. Hal ini tentunya akan mempengaruhi biaya pengangkutan sampah ke TPA, semakin banyak sampah yang diangkut ke TPA maka semakin besar pula biaya yang akan dikeluarkan untuk pengangkutan sampah. Oleh karena itu, pada penelitian ini akan dilakukan analisis pembiayaan pengelolaan sampah rumah tangga eksisting untuk kegiatan pengangkutan sampah dari TPS ke TPA, dimana analisis ini dilakukan untuk mengetahui kontribusi penerimaan retribusi sampah terhadap biaya pengangkutannya.

\section{METODOLOGI}

Diagram alir penelitian dengan judul "Analisis Biaya Pengangkutan Sampah Rumah Tangga Eksisting di Kota Cimahi" ini dapat dilihat pada Gambar 1. 


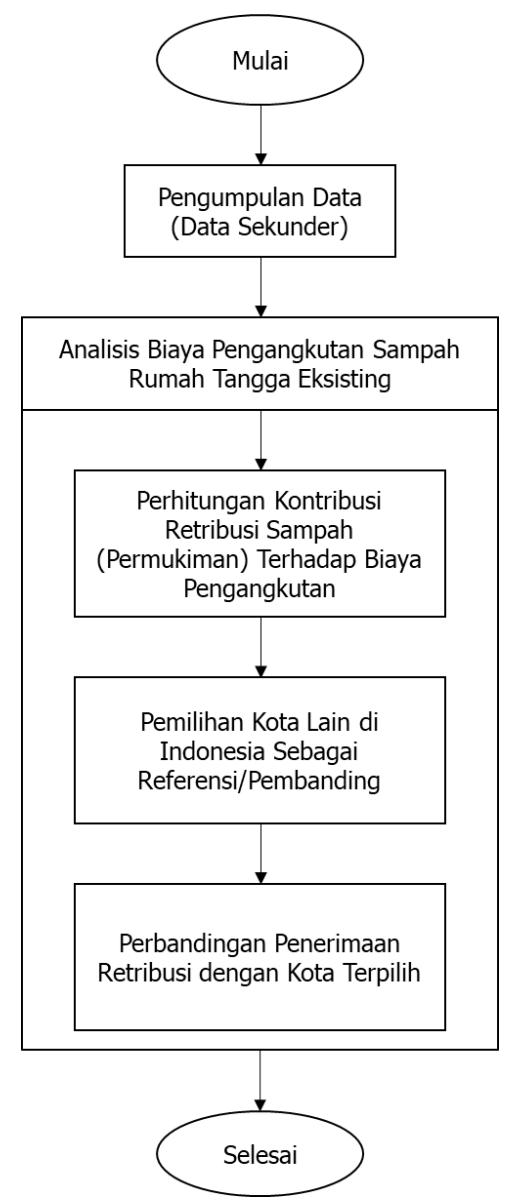

\section{Gambar 1. Diagram Alir Metodologi Penelitian}

Data yang dibutuhkan pada penelitian ini berupa data sekunder yang didapat dari beberapa instansi, yaitu Dinas Lingkungan Hidup (DLH) Kota Cimahi, Unit Pelaksana Teknis (UPT) Pelayanan Persampahan Kota Cimahi, dan Badan Pusat Statistik (BPS) Kota Cimahi. Berdasarkan Gambar 1, analisis biaya pengangkutan sampah rumah tangga eksisting di Kota Cimahi dilakukan dengan tahapan sebagai berikut :

- Menghitung besarnya kontribusi penerimaan retribusi sampah rumah tangga eksisting terhadap biaya pengangkutan sampah dari TPS ke TPA;

- Melakukan pemilihan referensi/pembanding dari kota lainnya di Indonesia yang memiliki kesamaan karakteristik dengan Kota Cimahi;

- Membandingkan penerimaan retribusi sampah di kota terpilih dengan penerimaan retribusi sampah di Kota Cimahi.

Tahapan pemilihan kota lain yang akan dijadikan referensi/pembanding diantara 99 kota di Indonesia dipilih berdasarkan kriteria berikut:

1. Jumlah penduduk;

2. Laju Pertumbuhan Penduduk (LPP);

3. Luas wilayah.

Jumlah penduduk dan laju pertumbuhan penduduk dapat mempengaruhi jumlah timbulan sampah kota, sedangkan data luas wilayah digunakan untuk mengetahui kepadatan 
penduduknya, dimana diasumsikan bahwa semakin tinggi kepadatan penduduk di suatu kota maka besar kemungkinan penggunaan lahan untuk TPA tidak tersedia, sehingga kota dengan luas wilayah kecil umumnya memanfaatkan TPA regional yang berada di Kota/Kabupaten lain.Pada analisis ini, perbandingan penerimaan biaya retribusi dibandingkan dengan Kota Yogyakarta.

\section{HASIL DAN PEMBAHASAN}

\subsection{Data Eksisting Persampahan Kota Cimahi}

\subsubsection{Timbulan dan Komposisi Sampah Kota Cimahi}

Berdasarkan data yang diperoleh dari Dinas Lingkungan Hidup (DLH) Kota Cimahi, timbulan sampah Kota Cimahi pada tahun 2016 adalah 289,1 ton/hari. Persentase timbulan sampah berdasarkan sumber sampahnya dapat dilihat pada Tabel $\mathbf{1}$.

\section{Tabel 1. Persentase Timbulan Sampah Berdasarkan Sumber Sampah Tahun 2016}

\begin{tabular}{|c|c|c|}
\hline Sumber Sampah & Timbulan Sampah (ton/hari) & Persentase (\%) \\
\hline Permukiman & 182,1 & 63 \\
\hline Pasar & 90,7 & 31 \\
\hline Kawasan komersil & 0,7 & 0,3 \\
\hline Institusi & 15,5 & 5,4 \\
\hline Jumlah & 289 & 100 \\
\hline
\end{tabular}

Berdasarkan Tabel 1, diketahui bahwa sumber sampah permukiman berkontribusi sebanyak $63 \%$, pasar berkontribusi sebanyak 31\%, kawasan komersil berkontribusi sebanyak 0,3\%, dan Institusi sebanyak 5,4\%. Penghasil sampah terbanyak di Kota Cimahi berasal dari aktivitas permukiman, sedangkan sumber sampah dengan persentase kontribusi sampah paling kecil berasal dari kegiatan di kawasan komersil. Berdasarkan data yang diperoleh dari DLH Kota Cimahi bahwa timbulan sampah perkapita untuk kawasan permukiman ditetapkan sebesar 2,49 liter/orang/hari atau 0,48 kg/orang/hari dengan berat jenis sampah sebesar $195,57 \mathrm{~kg} / \mathrm{m}^{3}$.Berdasarkan Tabel 2, dapat dilihat bahwa persentase jenis sampah terbanyak adalah sampah organik dengan persentase $50,6 \%$, dan jenis sampah paling sedikit adalah B3 rumah tangga dengan persentase $1,4 \%$.

Tabel 2. Komposisi Sampah di Kota Cimahi

\begin{tabular}{|c|c|c|c|c|}
\hline \multirow{2}{*}{ No } & \multicolumn{2}{|c|}{ Jenis Sampah } & \multirow{2}{*}{\multicolumn{2}{|c|}{$\begin{array}{c}\text { Komposisi Sampah Kota Cimahi (\%) } \\
\text { Rata-rata }\end{array}$}} \\
\hline & Makro & Mikro & & \\
\hline \multirow{2}{*}{1} & \multirow{2}{*}{ Organik } & Sisa Makanan & 38,6 & \multirow{2}{*}{50,6} \\
\hline & & Kayu,ranting dan daun & 12 & \\
\hline \multirow{5}{*}{2} & \multirow{5}{*}{ Kertas } & Duplex & 2,5 & \multirow{5}{*}{8,6} \\
\hline & & Kardus & 1,7 & \\
\hline & & Cone & 0,3 & \\
\hline & & Kertas Lusuh & 3,4 & \\
\hline & & Kertas HVS & 0,8 & \\
\hline \multirow{2}{*}{3} & \multirow{2}{*}{ Plastik } & Keras & 4,1 & \multirow{2}{*}{15,6} \\
\hline & & Lunak & 9,9 & \\
\hline
\end{tabular}




\begin{tabular}{|c|c|c|c|c|}
\hline \multirow{4}{*}{ No } & \multicolumn{2}{|c|}{ Jenis Sampah } & \multirow{2}{*}{\multicolumn{2}{|c|}{$\begin{array}{c}\text { Komposisi Sampah Kota Cimahi (\%) } \\
\text { Rata-rata }\end{array}$}} \\
\hline & Makro & Mikro & & \\
\hline & & Mainan & 0,4 & \\
\hline & & Emberan & 1,1 & \\
\hline \multirow{6}{*}{4} & \multirow{6}{*}{ Logam } & Alumunium & 0,3 & \multirow{6}{*}{3,1} \\
\hline & & Tembaga & 0,3 & \\
\hline & & Kuningan & 0 & \\
\hline & & Seng & 1,5 & \\
\hline & & Besi & 0,6 & \\
\hline & & Stainless & 0,4 & \\
\hline \multirow{3}{*}{5} & \multirow{3}{*}{ Kain } & Majun & 4,7 & \multirow{3}{*}{5,3} \\
\hline & & Kapas & 0,1 & \\
\hline & & Polyester & 0,5 & \\
\hline 6 & Gelas Kaca & Botol Gelas dan pecahan kaca & 3 & 3 \\
\hline \multirow{5}{*}{7} & \multirow{5}{*}{ B3 RT } & Baterai & 0,4 & \multirow{5}{*}{1,4} \\
\hline & & Bohlam/neon & 0,5 & \\
\hline & & Obat Nyamuk & 0 & \\
\hline & & Obat Kadaluarsa & 0,5 & \\
\hline & & Spray/aerosol & 0 & \\
\hline \multirow{6}{*}{8} & \multirow{6}{*}{ Lainnya } & Karet Ban & 1 & \multirow{6}{*}{12,5} \\
\hline & & Sandal & 1,8 & \\
\hline & & Spon & 0,1 & \\
\hline & & Stereofoam & 1,8 & \\
\hline & & Kapas & 0,1 & \\
\hline & & Popok & 7,7 & \\
\hline
\end{tabular}

Sumber : UPT Pelayanan Persampahan Kota Cimahi, 2016

\subsubsection{Biaya Pengelolaan Sampah dan Penerimaan Retribusi Sampah di Kota Cimahi}

Berdasarkan Tabel 3, diketahui bahwa biaya rata-rata untuk pengelolaan sampah Kota Cimahi pada tahun 2012-2016 sebesar Rp13.248.072.566, sedangkan biaya rerata yang diterima dari retribusi sampah, yaitu sebesar Rp1.016.350.400.

Tabel 3. Biaya Pengelolaan Sampah dan Penerimaan Retribusi Sampah di Kota Cimahi

\begin{tabular}{ccc}
\hline Tahun & $\begin{array}{c}\text { Total Biaya } \\
\text { Pengelolaan Sampah }\end{array}$ & $\begin{array}{c}\text { Penerimaan Retribusi } \\
\text { Sampah }\end{array}$ \\
\hline 2012 & Rp8.377.485.100 & Rp929.517.500,00 \\
\hline 2013 & $\mathrm{Rp} 5.050 .100 .000$ & $\mathrm{Rp} 953.948 .000,00$ \\
\hline 2014 & $\mathrm{Rp} 17.006 .130 .575$ & $\mathrm{Rp} 1.031 .929 .500,00$ \\
\hline 2015 & $\mathrm{Rp} 21.004 .261 .960$ & $\mathrm{Rp} 966.357 .000,00$ \\
\hline 2016 & $\mathrm{Rp} 14.802 .385 .197$ & $\mathrm{Rp} 1.200 .000 .000,00$ \\
\hline Rata-rata & Rp 13.248.072.566 & Rp 1.016.350.400 \\
\hline
\end{tabular}

Sumber : DLH Kota Cimahi, 2017 
Berdasarkan Tabel 4, dapat diketahui bahwa nilai rata-rata penerimaan retribusi sampah yang berasal dari kegiatan permukiman pada tahun 2012-2016 adalah sebesar Rp783.761.488.

\section{Tabel 4 Retribusi Sampah yang Diterima dari Kegiatan di Permukiman}

\begin{tabular}{cc}
\hline Tahun & $\begin{array}{c}\text { Penerimaan Retribusi } \\
\text { Sampah (Permukiman) } \\
\text { (Rupiah) }\end{array}$ \\
\hline 2012 & 686.060 .000 \\
\hline 2013 & 713.913 .000 \\
\hline 2014 & 821.279 .500 \\
\hline 2015 & 755.387 .000 \\
\hline 2016 & 942.167 .942 \\
\hline Rata-rata & $\mathbf{7 8 3 . 7 6 1 . 4 8 8}$ \\
\hline Sumber : DLH Kota Cimahi, 2017
\end{tabular}

3.2 Analisis Biaya Pengangkutan Sampah Rumah Tangga Eksisting di Kota Cimahi Pembiayaan pengelolaan sampah dibiayai dari dana Anggaran Pendapatan dan Belanja Daerah (APBD) Kota Cimahi dan retribusi pelayanan persampahan (Dinas Lingkungan Hidup Kota Cimahi, 2016).

Berdasarkan Perda Kota Cimahi No. 2 Tahun 2012, pengangkutan sampah dari Tempat Penampungan Sementara (TPS) ke Tempat Pembuangan Akhir (TPA), di lingkungan rumah tinggal setiap bulannya dikenakan retribusi sebesar Rp 8.000,- untuk klasifikasi kelas I (daya listrik diatas 1.300 watt), untuk klasifikasi kelas II sebesar Rp 6.500,- (daya listrik $500 \mathrm{~s} / \mathrm{d}$ 1.300 watt) dan untuk klasifikasi kelas III sebesar Rp 5.000,- (daya listrik 250 s/d 500 watt).

Berdasarkan kondisi eksisting, biaya retribusi sampah dipungut atas jasa pengangkutan sampah dari TPS ke TPA. Menurut Direktur Pengembangan PLP Direktorat Jenderal Cipta Karya Kementerian PU dalam Pedoman Teknis Penyusunan Studi Kelayakan Penyelenggaraan Prasarana dan Sarana Persampahan, disebutkan bahwa proporsi biaya pengumpulan terhadap total biaya pengelolaan sampah adalah sebesar $40 \%$, proporsi biaya pengangkutan terhadap total biaya pengelolaan sampah adalah sebesar $40 \%$ dan proporsi biaya pemrosesan akhir terhadap total biaya pengelolaan sampah adalah sebesar $20 \%$. Biaya pengangkutan sampah dari TPS ke TPA pada tahun 2012-2016 dapat dilihat pada Tabel 5.

\section{Tabel 5. Biaya Pengangkutan Sampah}

\begin{tabular}{ccc}
\hline Tahun & $\begin{array}{c}\text { Biaya } \\
\text { Pengangkutan }\end{array}$ & $\begin{array}{c}\text { Persen Penerimaan Retribusi Sampah } \\
\text { (Permukiman)Terhadap Biaya Pengangkutan }\end{array}$ \\
\hline 2012 & Rp3.350.994.040 & $20 \%$ \\
\hline 2013 & Rp2.020.040.000 & $35 \%$ \\
\hline 2014 & Rp6.802.452.230 & $12 \%$ \\
\hline 2015 & Rp8.401.704.784 & $9 \%$ \\
\hline 2016 & Rp5.920.954.079 & $16 \%$ \\
\hline Rata-rata & Rp 5.299.229.027 & $\mathbf{1 9 \%}$ \\
\hline
\end{tabular}

Sumber: Hasil Pengolahan Data, 2017 
Berdasarkan Tabel 5 diketahui bahwa biaya pengangkutan dari tahun 2012 ke 2013 menurun dari Rp 3.350.994.040 menjadi Rp 2.020.040.000, sedangkan dari tahun 2013 sampai 2015 mengalami kenaikan berturut-turut dari Rp 2.020.040.000 menjadi Rp 6.802.452.230 dan Rp 8.401.704.784, lalu terjadi penurunan lagi dari tahun 2015 ke 2016 menjadi Rp 5.920.954.079. Naik atau turunnya biaya pengangkutan per tahun kemungkinan dipengaruhi oleh kebutuhan alat angkut setiap tahunnya, biaya pemeliharaan dan operasional alat angkut.

Contoh perhitungan baris kedua untuk Tabel 5(Tahun 2012):

\section{Diketahui :}

- Biaya pengelolaan sampah $\quad=$ Rp8.377.485.100

- Penerimaan retribusi sampah dari permukiman $\quad=$ Rp686.060.000

\section{Perhitungan :}

- Biaya pengangkutan $=40 \% \times$ biaya pengelolaan sampah

$$
\begin{aligned}
& =40 \% \times \text { Rp8.377.485.100 } \\
& =\text { Rp3.350.994.040 }
\end{aligned}
$$

- Persen penerimaan retribusi sampah (permukiman) terhadap biaya pengangkutan $=$ $\frac{\operatorname{Rp} 686.060 .000}{\operatorname{Rp~} 3.350 .994 .040} \times 100 \%=20 \%$

Berdasarkan perhitungan tersebut, diketahui bahwa persentase penerimaan retribusi sampah (permukiman) terhadap biaya pengangkutan pada tahun 2012 adalah sebesar 20\%.

Berdasarkan Tabel 5, biaya rata-rata pengangkutan sampah dari tahun 2012-2016 mencapai Rp5.299.229.027, sedangkan penerimaan rerata retribusi sampah yang berasal dari sumber sampah permukiman, yaitu sebesar Rp783.761.488 (lihat pada Tabel 4) atau jika dipersentasekan kontribusi penerimaan retribusi sampah dari permukiman terhadap biaya pengangkutan sampah hanya 19\% (lihat pada Tabel 5). Sehingga dalam pengelolaan sampah di Kota Cimahi, penerimaan retribusi sampah memiliki kontribusi yang relatif kecil dan tidak dapat dijadikan sumber anggaran utama. Menurut Kementerian PUPR Dirjen Cipta Karya (2015), idealnya diperlukan sinergitas alokasi anggaran dana untuk pengelolaan sampah dari APBN sebesar 10\%, APBD sebesar 26\% serta dari (Coorporate Social Responsibility) CSR dan masyarakat sebesar $64 \%$.

Selanjutnya akan dilakukan perbandingan penerimaan retribusi sampah (permukiman) di Kota Cimahi dengan penerimaan retribusi sampah (permukiman) kota lain di Indonesia yang memiliki karakteristik kota yang mirip dengan Kota Cimahi. Pemilihan kota yang akan dijadikan pembanding/referensi, yaitu dengan membandingkan jumlah penduduk, laju pertumbuhan penduduk dan luas wilayahnya. Berikut pada Tabel $\mathbf{6}$ merupakan hasil perbandingan Kota Cimahi dengan Kota Yogyakarta, setelah dilakukan perbandingan karakteristik dengan 98 Kota lainnya di Indonesia.

\section{Tabel 6. Perbandingan Jumlah Penduduk, Laju Pertumbuhan Penduduk dan Luas} Wilayah Kota-Kota di Indonesia

\begin{tabular}{ccc}
\hline Kriteria & Kota Cimahi & Kota Yogyakarta \\
\hline Jumlah Penduduk Tahun 2016 (jiwa) & 594.020 & 417.744 \\
\hline LPP (\%) & 1,43 & 1,27 \\
\hline Luas Wilayah $\left(\mathrm{km}^{2}\right)$ & 40,25 & 46 \\
\hline TPA Regional & Sarimukti di KBB & Piyungan di Kab. Bantul \\
\hline Sumber : BPS Provinsi Jawa Barat, 2017 dan BPS Provinsi D.I. Yogyakarta, 2017
\end{tabular}


Setelah dilakukan perbandingan karakteristik 99 kota di Indonesia, maka kota yang memiliki karakteristik yang hampir sama dengan Kota Cimahi adalah Kota Yogyakarta. Berikut beberapa hal yang menjadi dasar pertimbangan pemilihan Kota Yogyakarta sebagai perbandingan/referensi:

1. Setelah dibandingkan dengan seluruh kota di Indonesia, jumlah penduduk tahun 2016 dan laju pertumbuhan penduduk tahun 2010-2016 yang paling mendekati adalah Kota Yogyakarta. Jumlah penduduk tahun 2016 dan laju pertumbuhan penduduk tahun 2010-2016 Kota Cimahi, yaitu 594.020 jiwa dan 1,43\%, sedangkan jumlah penduduk tahun 2016 dan laju pertumbuhan penduduk tahun 2010-2016 Kota Yogyakarta, yaitu 417.744 jiwa dan 1,27\%;

2. Berdasarkan luas wilayah, Kota Yogyakarta juga memiliki luasan yang hampir sama dengan Kota Cimahi, dimana luas Kota Cimahi adalah 40,25 $\mathrm{km}^{2}$ dan luas Kota Yogyakarta adalah $46 \mathrm{~km}^{2}$;

3. Selain itu, Kota Yogyakarta juga tidak memiliki TPA sendiri, sehingga memanfaatkan TPA Piyungan di Kabupaten Bantul, sama halnya dengan Kota Cimahi yang memanfaatkan TPA Sarimukti di Kabupaten Bandung Barat.

Setelah didapat kota yang dapat dijadikan referensi/pembanding, terkait pembiayaan pengelolaan sampah di Kota Yogyakarta diketahui bahwa kontribusi rerata retribusi sampah terhadap biaya pengelolaan sampah tahun $2001-2007$ adalah $16 \%$, sedangkan sebesar $84 \%$ berasal dari anggaran pemerintah (Faizah, 2008),sedangkan di Kota Cimahi 19\% biaya berasal dari masyarakat dan sisanya sebesar $81 \%$ berasal dari anggaran pemerintah. Hal ini menunjukkan bahwa penerimaan retribusi sampah di Kota Cimahi masih relatif lebih baik dibandingkan dengan Kota Yogyakarta.

\section{KESIMPULAN}

Berdasarkan hasil analisis terhadap biaya pengangkutan sampah rumah tangga pada kondisi eksisting di Kota Cimahi, biaya rata-rata pengangkutan sampah dari tahun 2012-2016 mencapai Rp5.299.229.027, sedangkan penerimaan rerata retribusi sampah yang berasal dari sumber sampah permukiman, yaitu sebesar Rp783.761.488 atau jika dipersentasekan kontribusi penerimaan retribusi sampah dari permukiman terhadap biaya pengangkutan sampah hanya $19 \%$. Sehingga, dalam pengelolaan sampah di Kota Cimahi, penerimaan retribusi sampah memiliki kontribusi yang relatif kecil dan tidak dapat dijadikan sumber anggaran utama. 


\section{DAFTAR RUJUKAN}

Badan Pusat Statistik Kota Cimahi. (2016). Kota Cimahi Dalam Angka 2016.

Dinas Lingkungan Hidup Kota Cimahi (2016). Rencana Induk Persampahan Kota Cimahi Tahun 2017-2037.

Direktur Pengembangan PLP Direktorat Jenderal Cipta Karya Kementerian Pekerjaan Umum. (2015). Pedoman Teknis Penyusunan Studi Kelayakan Penyelenggaraan Prasarana dan Sarana Persampahan.

Faizah. (2008). Pengelolaan Sampah Rumah Tangga Berbasis Masyarakat (Studi Kasus di Kota Yogyakarta). Universitas Diponegoro, Semarang.

Kementerian Pekerjaan Umum dan Perumahan Rakyat Direktorat Jenderal Cipta Karya. (2015). Pengembangan Pengelolaan Persampahan.

Peraturan Daerah Kota Cimahi Nomor 2 Tahun 2012 Tentang Retribusi Jasa Umum.

Peraturan Menteri Pekerjaan Umum Nomor 3 Tahun 2013 Tentang Penyelenggaraan Prasarana dan Sarana Persampahan.

SNI 3242:2008 Tentang Tata Cara Pengelolaan Sampah di Permukiman. 